This is an electronic reprint of the original article. This reprint may differ from the original in pagination and typographic detail.

Author(s): Lähdesmäki, Tuuli

Title: $\quad$ Comparing Notions on European Cultural Heritage in EU Policy Discourse and Scholarly Discussion

Year: $\quad 2016$

Version:

Please cite the original version:

Lähdesmäki, T. (2016). Comparing Notions on European Cultural Heritage in EU Policy Discourse and Scholarly Discussion. International Journal of Interdisciplinary Social Sciences, 11, 1-14. https://doi.org/10.18848/1833-1882/cgp/1-14

All material supplied via JYX is protected by copyright and other intellectual property rights, and duplication or sale of all or part of any of the repository collections is not permitted, except that material may be duplicated by you for your research use or educational purposes in electronic or print form. You must obtain permission for any other use. Electronic or print copies may not be offered, whether for sale or otherwise to anyone who is not an authorised user. 


\title{
Comparing Notions on European Cultural Heritage in EU Policy Discourse and Scholarly Discussion
}

\author{
Tuuli Lähdesmäki, University of Jyväskylä, Finland
}

\begin{abstract}
Cultural heritage is an idea and a concept repeatedly brought up in current EU policy discourse. In recent years the European Commission has launched several initiatives which aim to foster the idea of a common European cultural heritage. The idea is also often referred to in scholarly discussion. There has been vivid discussion in academia about the possibility of a European cultural heritage and what it could be grounded upon. What is a European cultural heritage? How has it been explicated and defined in recent EU policy discourse and scholarly discussion? Through qualitative content analysis of diverse EU policy documents and selected scholarly publications, the article clarifies the multifaceted meanings of a European cultural heritage, compares the similarities and differences between the political and scholarly notions of it, and discusses the interaction and interrelatedness of political and scholarly discussions about a European cultural heritage. As a result, the article brings out diverse phenomena, such as values, events, personalities, styles, architecture, urbanity, borders, a conflicting past, and the EU integration process, through which a European cultural heritage has been defined and presents these definitions categorized on the basis of the tangible, intangible, communal, and spatial dimensions of heritage.
\end{abstract}

Keywords: European Cultural Heritage, European Union, Policy, Scholarly Discussion, Communality, Spatiality, Tangible Heritage, Intangible Heritage

\section{Culture as a Symbolic and Poetic Dimension of the European Union}

$\mathrm{T}$ The foundation of the European Union (EU) lies in economic and political cooperation and integration. Nevertheless, culture has an important role in today's EU politics and policies. The strengthening of the cultural political objectives of the EU has been discussed much in academia (O'Callaghan 2011; Näss 2010). On one hand, culture has been perceived as a relatively new focus in EU policy discourse. On the other hand, it has been considered one of the underlying ideas that have motivated the creation and building of the European Community and, later, the EU. Several scholars (e.g., Rosamond 2000; Sassatelli 2006; Näss 2009) have pointed out how, since the early years of the union, cultural and social cohesion and integration in the EU have been expected to emerge as a "spill-over" of successful cooperation in the core areas of the EU, i.e., economy and trade.

The EU's increased interest in culture and the various policies and practices created to promote and govern it have been recently identified in academia as the "third wave" of the European integration process (Karlsson 2010; Jarausch 2010). The third wave-brought out after the more or less realized waves of economic and political unification-includes complex and strongly disputed processes, such as promoting a particular European amalgam of knowledge, attitudes, and values (Karlsson 2010, 38), searching for common cultural roots, and attempts to create a shared European memory that would transcend national differences in the interpretation of the past (Jarausch 2010). During the past decade, these processes have also been discussed in academia as cultural Europeanization (e.g., Delanty 2005; Delanty and Rumford 2005; Sassatelli 2008; Jones and Subotic 2011).

The EU's interest in culture and its attempts to utilize culture as a policy tool do not, however, reflect the share of the budget the EU allocates for this. Only about one percent of the EU budget has been directed to cultural actions and projects in the past decade. The EU's interest in culture is very much a rhetorical and discursive operation and thus EU cultural policy has a profoundly symbolical nature. As Klaus Patel describes it: "[C]ultural policy is designed both to

The International Journal of Interdisciplinary Social Sciences: Annual Review

Volume \#, Issue \#, 20\#\#, www.thesocialsciences.com

(C) Common Ground Publishing, Tuuli Lähdesmäki, All Rights Reserved

Permissions: cg-support@commongroundpublishing.com

ISSN: 1833-1882 (Print) 
enlarge the scope of EU power and authority and to win the hearts and minds - and not just the hands and muscle - of the European citizens" $(2013,2)$. The symbolical nature of EU cultural policy is also due to "the odd position of being at the same time limited in reach and scope, yet distinctively oriented to the ambitious objectives of identity-building", as Monica Sassatelli $(2009,47)$ notes. The symbolical nature of the policy is highlighted by the emotional and affective rhetoric used in EU policy discourse. The policy rhetoric commonly cites, e.g., the idea of a common cultural heritage, values, history, and memory, and a European identity, albeit their contents are rarely explicitly explained. Indeed, the EU's political discourse has a strong poetic dimension (Banús 2015) in its emphasis on culture, heritage, and identity. This poetic dimension brings to EU policy discourse lofty and sublime tones that lift the meanings of the discourse above everyday practices and "grey" political decision-making. The poetic dimension has functional utility in the EU policy discourse: discussion about a sense of belonging, identification with Europe, and common cultural roots as their basis aims to influence European citizens on the emotional and affective level, and justify the promotion of cultural integration in the EU.

Heritage is an idea repeatedly brought up and referred to in current EU policy discourse; it is a central concept closely related to the "third wave" of the European integration process, the symbolical nature of EU cultural policy, and the poetic dimension of the union. In addition to being present in EU policy discourse, the idea of a common European cultural heritage has also interested several scholars. There has been vivid discussion in academia about the possibility of a European cultural heritage and what it could be grounded upon. What is a European cultural heritage? How has it been explicated and defined in recent EU policy discourses and scholarly discussions? The main objectives of the article are to clarify the multifaceted meanings of a European cultural heritage, compare the similarities and differences found in political and scholarly notions of it, and thereby understand the interaction and interrelatedness of political and scholarly discussions about European cultural heritage.

The article proceeds from presenting the research data and methods to conceptualizing the key concept of the study-cultural heritage. In this section cultural heritage is discussed in relation to spatiality and communality and explored as including both tangible and intangible dimensions. The conceptualization is followed by a discussion of the notions of a European cultural heritage in selected scholarly studies and policy documents of the core EU initiatives on heritage. The article ends with a comparison of and concluding remarks on the similarities and differences of the notions of the idea in scholarly and political contexts and a discussion about the definitions of a European cultural heritage categorized on the basis of the tangible, intangible, communal, and spatial dimensions of heritage.

\section{Data and Methods}

The idea of a common culture in Europe has been included in EU policy discourse since the Maastricht Treaty (1992). Since then, EU policy discourse has emphasized European culture(s) as being characterized by both distinct cultural units and shared cultural roots. The common cultural heritage in particular has been given an important rhetorical role in the production of unity, communality, and cultural integration in the EU (Lähdesmäki 2012). EU policy discourse about heritage is concretized and put into practice in various EU heritage initiatives. During the past fifteen years, the EU has launched several cultural initiatives, projects, and events aiming to foster the idea of a common European cultural heritage.

The empirical study in the article focuses on two types of data. The first type of data consists of policy documents of the EU initiatives aiming to promote and foster the idea of a European cultural heritage. The European Heritage Label and the European Capital of Culture were selected as the main cases for a closer investigation of the policy discourse. The most recent and broadest EU heritage initiative, the European Heritage Label, was launched in 2006 as an intergovernmental initiative but turned into an official EU action already in 2011. In this initiative, the European Commission annually awards European sites with the Label on the basis 
of their applications. The labelled sites are first pre-selected at the national level and the final selection is made by an expert panel appointed at the EU level. The European Heritage Label was created by using the longest-running and perhaps most influential EU cultural initiative, the European Capital of Culture, as its case in point. The European Capital of Culture was launched in 1985 as an intergovernmental initiative and turned into an official EU action in 1999. As in the case of the European Heritage Label, the European Commission annually designates cities as European Capitals of Culture on the basis of their applications. The candidate cities first compete for the designation between national candidates among which national panels suggest the final candidates to the Commission. In both initiatives the selection criteria emphasize the importance of pointing out the European dimension of culture, heritage, and/or history of the city or site. Although the European Capital of Culture has a broader cultural and urban focus than the European Heritage Label, the initiative nevertheless includes strong emphasis on promoting cultural heritage (Lähdesmäki 2012). Data on EU policy discourse were gathered from EUR-Lex, a database of legal texts of the European Union, and from the official web site of the European Commission.

The second type of data consists of selected scholarly publications in which the authors discuss European culture and identity and seek features and elements which could be regarded as a basis for a common European cultural heritage. These publications (monographs, edited volumes, and journal articles) were gathered by using scholarly databases, such as the EBSCO Academic Search Elite (ASE), and selecting for the discussion publications in which the idea of a European cultural heritage is the focus or forms one of the focuses of the study and/or in which the idea is further discussed.

The data were analysed using qualitative content analysis (Tesch 1990; Miles and Huberman 1994) guided by the research questions: What is a European cultural heritage and how is it explicated and defined in the data? Thus, the analysis focused on mapping the variety of notions of a European cultural heritage and perceiving how these notions are founded upon tangible, intangible, communal, and spatial dimensions of heritage.

\section{Conceptualizing Cultural Heritage}

Concepts are essential to the production of scholarly knowledge and in forming theoretical paradigms. In addition, scholarly concepts are easily adopted from scholarly discussions in political discourse. The use of ambiguous concepts involves the use of power: they are a means to give a certain kind of meaning to complex phenomena and to legitimate and justify certain points of view, ideas, and ideologies connected to them. Thus vague, complex, or ambiguous concepts are easily politicized (Lähdesmäki 2016).

Cultural heritage is an extremely ambiguous and fluid concept. During the past century, its meanings have transformed from the idea of goods inherited from forefathers to the sense of cultural roots, identity, and belonging (cf. Lowenthal 1998, 4). Simultaneously, the concept has faced a semantic transfer in heritage discourses - the idea of cultural heritage is no longer defined on the basis of its tangible material aspect (Vecco 2010). Indeed, the concept of cultural heritage has faced a rapid change in the Western world: the status of cultural heritage has also been given to objects that do not follow the traditional historical and national emphasis of the concept. Objects alone are no longer necessarily considered cultural heritage, but rather the cultural values the objects promote, their role in the creation of identities, and their capacity to interact with memory have been perceived as crucial selection criteria of cultural heritage. These developments have also made it possible to recognize intangible cultural heritage (Vecco 2010). UNESCO adopted the convention on intangible cultural heritage in 2003. In it, intangible cultural heritage means "the practices, representations, expressions, knowledge, skills - as well as the instruments, objects, artefacts and cultural spaces associated therewith-that communities, 
groups and, in some cases, individuals recognize as part of their cultural heritage" (UNESCO 2003, 2).

The conceptual extension of the idea of cultural heritage has not, however, made the concept any less ambiguous. While Laurajane Smith (2006) emphasizes that in an epistemological sense all heritage is intangible due to its social values and impact, Kristin Kuutma (2012) notes that the concept of heritage is in fact used to sanction, give status, and make material the intangibilities of culture and human experience. While the epistemological demarcation between tangible and intangible seems to be difficult to draw, the demarcation is, however, put forward by heritage politics and industries. As Kuutma (2012) states, the polarization into tangible and intangible heritage is mainly organizational and political and applied to demarcate target spheres and areas of expertise inside heritage industries. The scholarly attempts to clarify the concept of heritage by categorizing it into cultural and natural heritage have also turned out to be problematic (Ahmad 2006; Lowenthal 2005). As David Lowenthal argues: "no aspect of nature is unimpacted by human agency, no artefact devoid of environmental impress" $(2005,81)$.

Due to the recent political interests in a cultural heritage in Europe, the concept of cultural heritage has been discussed in various policy documents. The most direct attempt to define the concept is presented in the Council of Europe Framework Convention on the Value of Cultural Heritage for Society. In it, the concept is defined as follows:

[C]ultural heritage is a group of resources inherited from the past which people identify, independently of ownership, as a reflection and expression of their constantly evolving values, beliefs, knowledge and traditions. It includes all aspects of the environment resulting from the interaction between people and places through time. (CofE 2005, 2)

The definition brings to the fore tangible, intangible, communal, and spatial dimensions of cultural heritage. In recent scholarly discussions, the concept has been defined in various theoretical frameworks and discussed in different disciplinary contexts. These discussions have also commonly focused on the communal and spatial dimensions of cultural heritage. Indeed, various scholars have emphasized how cultural heritage is inherently a spatial phenomenon: all heritage, both tangible and intangible, occurs somewhere (Graham, Ashworth, and Tunbridge 2000; Ashworth, Graham, and Tunbridge 2007). Scholars have also emphasized cultural heritage as a social and communal process - as "the use of the past as a cultural, political and economic resource for the present" (Ashworth, Graham, and Tunbridge 2007, 3) — and as meanings placed on tangible artefacts or intangible forms of the past and the representations created from them (Graham, Ashworth, and Tunbridge 2000; Graham 2002). In these discussions, the communal and spatial dimensions of cultural heritage intertwine. As Gregory J. Ashworth, Brian J. Graham, and John E. Tunbridge (2007) note, one of the fundamental attributes of cultural heritage is its explicit role as the key factor in creating representations of place as a core attribute of identity. According to them, heritage as a process and practice fulfils a multiplicity of roles in contemporary societies, such as "fostering and strengthening of the identification of peoples with their governments and jurisdictions on various spatial scales; the identification of individuals with social groups; and the construction of images of place for promotion in various markets" (Ashworth, Graham, and Tunbridge 2007, 2). Indeed, various empirical studies have brought to the fore strong functional and conceptual links between identity, history, heritage, memory, and place (e.g., Foote 1997; Yeoh and Kong 1999). Especially national and ethnic identities include strong geographical dimensions in which the past and heritage are seen as being anchored to various physical places and landscapes (e.g., Said 1985).

The recent theoretical discussions on identities rely on "multilayeredness" - an idea recently discussed in academia using diverse concepts and from different theoretical points of view in order to describe the "overlapping," "nested," "cross-cutting," "mixed," "hybrid," or "coexisting" nature of identities (see, e.g., Delanty and Rumford 2005, 51; Risse 2010, 23-25; Kohli 2000). As Thomas Risse (2003) notes, identities are invoked in a context-dependent way: People 
have various different identities which become activated in certain situations or circumstances. The same cultural phenomena, qualities, and issues can be considered as markers of different identities in different situations or circumstances. Similarly, cultural heritage can be perceived as multilayered: certain layers of meanings of heritage are activated in certain discourses, policies, and practices. The following sections focus on exploring which layers are taken to the fore in defining a European cultural heritage in EU policy discourse and in scholarly discussions.

\section{Notions on European Cultural Heritage in Scholarly Discussion}

Defining a European cultural heritage is not a neutral, objective, or value-free process. It means taking a stand on the idea of shared cultural values, understanding of the past, and communality that transcend the national level but are nonetheless not perceived as global or universal (Lähdesmäki 2015). Gerard Delanty (2009) has emphasized the impossibility of speaking of a European cultural heritage without considering its political meaning: European cultural and political heritages cannot be separated. According to him, the movement from history to heritage embraces "an evaluation of the past in order for the present to judge what legacy it should derive from history. The debate about European heritage is very much a question of identifying the cultural resources that might be relevant to the current challenges of European societies" (Delanty 2009, 36.).

In academia, scholars have presented varying views on the possibility of a European cultural heritage, and if such does exist, what it could be grounded upon (e.g., Ashworth and Larkham 1994). Critical scholars have asked what might be the European dimension of a heritage that goes beyond the mere sum of national icons and thus still promotes the nation (Sassatelli 2006, 29), questioned the possibility of common European commemoration and heritage practices due to the lack of a singular "European people" (Delanty 2009, 37), or seen it impossible to prescribe a European heritage in thematic terms due to the diversity of the continent (Larkham 1994, 270). Indeed, nation-states still form the fundamental ideological basis, territorialized political sphere, and institutionalized forum of practice for the fostering, preserving, and meaning-making of cultural heritage (Lähdesmäki 2015).

Nevertheless, several scholars have recognized possible common grounds for perceiving and outlining a common European cultural heritage. Urbanity and urban civilization, i.e., the development of a mercantile bourgeois city as an "urban organism," has been perceived as one of the common attributes of Europe and components of a common European cultural heritage (Benevolo 1995; Sassatelli 2009), albeit urban areas and especially capitals are at the same time the typical loci of national culture (Jenkins 2008; Sassatelli 2009). In addition to urban development and dynamics in the present and past Europe, scholars have also more strictly emphasized material urban settings as a European cultural heritage. For example, Gregory J. Ashworth and Brian Graham (1997) have fixed the idea of a European cultural heritage to the historical environment of European cities. According to them:

The problem is that there is relatively little evidence of Europeans focusing on the meaning of Europe. One possible exception might be articulated through "Europe of the cities" (the environment in which most Europeans live, work, and recreate) but specifically the "Europe of the historic cities." If pressed to define the content of what is typically European as opposed to appertaining to some other continent, it is likely that images of Florence, Bath, and Heidelberg, of piazzas, boulevards, and buildings, would be evoked among many who do not live in these particular environments, cities or even countries. In these senses a European heritage already exists in the European imagination. (Ashworth and Graham 1997, 387) 
Some scholars have taken an art historical point of view to the idea of a European cultural heritage and linked it more specifically to architecture and architectural heritage. Gerard Delanty and Paul Jones write about the architectural styles and movements in Europe as follows:

Architecture has thus been the quintessentially universalistic expression of civilization since all the great architectural designs - classical Greek, Romanesque, Renaissance, Gothic, Baroque, Rococo, Modernist-have been universalistic in their selfunderstanding and one of the most important expressions of European civilization transcending the particularism of its national cultures. (Delanty and Jones 2002, 453-4)

In this view, universalist discourse about heritage as an expression of civilization is amalgamated with the idea of a European dimension of heritage that transcends the national layers of meanings and interpretations of heritage.

In addition to urban settings, Gregory J. Ashworth and Brian Graham have approached the idea of a European cultural heritage by introducing two conceptual categories: "the idea of European unity" and "the unity of European ideas" (1997, 383-4). In their view, the heritage of "the idea of European unity" is based on recent narratives of building the European Union, its institutions, principles, and values, while the heritage of "the unity of the European ideas" comprises ideas, values, and activities that are perceived to be continental rather than only national. Similarly, John E. Tunbridge has discussed "a European heritage identity" as consisting of "many transnational components which exist within the continent" $(1994,132)$. As examples of these components, Tunbridge mentions the legacy of historical imperial powers in Europe: the Hanseatic origins of several Northern European cities; Central European cities united by a Habsburg identity; the heritage of the Celtic and Norse fringes of the continent; and the common legacy of Rome "underpinning the heritage of the greater part of Europe" (1994, 132). Approaching heritage as being based on the idea of European unity faces various difficulties. As Ashworth and Graham note, "there are just very few resources, whether buildings, events or personalities from the European past that could be used to shape such a European heritage in competition with the resources available at the national level" (1997, 383). Also, the latter approach is problematic as common "continental" ideas, values, activities, and legacies in Europe are ambiguous and difficult to define. In addition, the transnational components of a European heritage suggested by Tunbridge represent the legacy of expansive powers and/or imperial conquests.

Peter Howard and Gregory J. Ashworth have called these two conceptual categories "the heritage of the pan-European idea" and "the heritage of pan-European ideas" and broadened the view on the European dimension of heritage by taking into the discussion "the heritage of European conflict" and European organizations as producers of heritage, because "both above ideas for structuring a content of a European heritage founder on the dissonant nature of the European historical narrative" (Ashworth and Howard 1999, 69). The current EU policy discourse aims to foster a harmonious and liberalist view on European cultural heritage, although the history of Europe is filled with various illiberal views, violations of rights, and wars. Gregory J. Ashworth and Peter J. Larkham (1994) rightly ask how we should deal with Europe's "dissonant heritage?" They state:

Europe's long history of war, pogrom and persecution between nations, classes, races and religions has left its own legacies, which markedly contradict any theme of harmonious unity. Are these to be ignored, or somehow reinterpreted within the new European heritage product? (Ashworth and Larkham 1994, 4)

As an answer to this question, several scholars (e.g., Tunbridge 1994; Delanty 2002; Kuipers and Schofield 2004) have also emphasized various conflicts and collective traumas as the common ground for a shared European history and cultural heritage. Particularly the scholarly literature on 
European historical memory has often focused on the two World Wars and the traumas of the Holocaust (e.g., Niznik 2013; Pakier 2010; Pakier and Stråth 2010). Scholars have discussed the Holocaust as "Europeanized" from national histories into a European-wide trauma (Delanty 2002; Diner 2003) and perceived it as "canonized" as a particularly European dimension of history (Karlsson 2010, 40). In addition to the World Wars and the Holocaust, scholars have located other unifying elements in the European past; religious and class-based conflicts and "a new era of multicultural conflicts over cultural rights and anti-globalisation conflicts today" (Delanty 2002, 354). This kind of point of view frames a European cultural heritage with sensitive, emotive, and problematic meanings commonly discussed in heritage studies with the concept of "difficult heritage" (for more about the concept, see Macdonald 1999). The concept has particularly been used in discussions on the heritage of the Holocaust and the major wars and violent conflicts of the twentieth century.

The idea of a common European cultural heritage faces various challenges due to Europe's conflicting past and diverse demarcation lines drawn between national, regional, cultural, linguistic, and religious units in Europe. In general, the diversity and the real and imagined fragmentation of Europe into smaller spatial and communal units challenge the link between the idea of a common heritage and place-identity on a European scale. In fact, some scholars (DolffBonekämper 2004) have perceived boundaries and borders as such as an inherent part of Europe's shared heritage. As Gabi Dolff-Bonekämper notes:

Why treat borders as heritage? Because Europe's nation states, and all the territorial and national units which preceded them, have left us a legacy of borders, borders old or recent (sometimes very recent), accepted or contested, fortified or open, threatening or all but invisible. These borders are lines, but only on the map. In reality, they stand for something bigger - border regions, which are also transit zones, places where cultures have met and mingled or, like many armies on the same ground, clashed. The architectural and landscape traces of the history made on those borders - the defences and gateways, the checkpoints and meeting places, the symbols of co-operation or rejection-together form a heritage which we consider precious. Throughout Europe, they are places where shared memories converge. (Dolff-Bonekämper 2004, 11)

Although the concept of a European cultural heritage is often used in studies exploring cultural interaction in Europe, a European identity, the European integration process, EU cultural initiatives, and EU cultural policy, the concept is often used without further discussion of its meanings (Lähdesmäki 2016). Scholarly publications that use the concept rarely focus on discussing a European cultural heritage as such. The concept is commonly embedded in discussions on cultural, social, and political processes in general and in examination of various topics more or less closely related to the idea of heritage. This kind of use of the concept makes the idea of a European cultural heritage vague: without an accurate definition, the concept remains ambiguous, with only little analytical use in research.

\section{Notions on European Cultural Heritage in EU Policy Discourse}

In EU policy discourse, as well as often in scholarly discussion, the concept of a European cultural heritage is left without further discussion or more explicit definition. EU policy documents do not fix the concept to any particular cultural or historic characteristics. As Claske Vos states, the notion of a European cultural heritage is intentionally vaguely outlined, since explicit pronouncements on what makes a heritage "European" might lead to various conflicts and problems regarding the ownership of that heritage $(2011,226)$.

In EU policy discourse, the idea of cultural heritage itself includes various positive, affirmative, and uplifting features and is thus perceived as "a major asset for Europe and an important component of the European project" (EC 2014, 36) to be utilized for promoting the 
EU's various social, cultural, educational, and economic goals. In the European Heritage Label, the policy discourse aims, for example, to strengthen "European citizens' sense of belonging to the European Union" on the basis of "shared values and elements of European history" (EC 2011, 2-3) and to promote "EU citizenship by preserving and facilitating access to historical sites of shared European memory" (EP 2012, 154).

Although EU policy discourse emphasizes various positive capacities of cultural heritage to create and enhance social capital and communality among Europeans, EU memory and history politics have also paid attention to the conflicting past of Europe and its various crimes, violent confrontations, and terrors which have left both material and social traces in Europe and caused demarcation lines to be drawn between Europeans. The EU's attention to the conflicting past has particularly focused on the two World Wars, the Holocaust, and the twentieth century totalitarianisms. Preceded by initiatives after the 1990s to increase awareness of the Holocaust, and with the EU's Eastern expansion also awareness of the crimes of communist regimes, efforts regarding European memory politics were supported in particular by the European Commission's Europe for Citizens Programme launched in 2006 (Prutsch 2013). In its current version, the significance of remembrance has even strengthened. In addition, the EU has in various other programs and initiatives paid attention to the memory of crimes caused by twentieth century European totalitarianisms (EC 2010). For example, the European Parliament's Resolution on European Conscience and Totalitarianism in 2009 includes several actions that promote remembrance of the victims of totalitarian and authoritarian regimes in Europe (EP 2010).

Remembrance of the horrors of Europe's recent past serves a clear purpose in the EU's policy discourse: the "appropriate preservation of historical memory, a comprehensive reassessment of European history and Europe-wide recognition of all historical aspects of modern Europe will strengthen European integration" (EP 2010, 27). Indeed, European integration is a recurring topic in EU policy discourse about a European heritage, history, and memory. The discourse commonly links European cultural heritage to the development of the EU and the history of European integration. This linkage is turned into practice in the EU's heritage initiatives. For example, the decision on the European Heritage Label requires that the candidate sites "must have played a significant role in the history and culture of Europe and/or the building of the Union" (EC 2011,4) and that they must therefore demonstrate, for example, "their place and role in the development and promotion of the common values that underpin European integration" (EC 2011, 4).

The idea of shared values, European integration, and European cultural heritage forms a multifaceted rhetorical amalgam in EU policy discourse. In it, the idea of a European cultural heritage stems from general societal ideals and political principles. These ideals and principles are perceived as being manifested in a European cultural heritage, but also as being a kind of heritage themselves. In the Treaty on European Union itself a group of common values are presented as the core foundation of the union. The Treaty is described as "[d]rawing inspiration from the cultural, religious and humanist inheritance of Europe, from which have developed the universal values of the inviolable and inalienable rights of the human person, freedom, democracy, equality and the rule of law" (EC 2012, 326). Similar values are brought to the fore in the policy discourse justifying the establishment of the European Heritage Label. The rhetoric in the decision links the support to European integration, common values, and promotion of a European cultural heritage:

For citizens to give their full support to European integration, greater emphasis should be placed on their common values, history and culture as key elements of their membership of a society founded on the principles of freedom, democracy, respect for human rights, cultural and linguistic diversity, tolerance and solidarity. (EC 2011, 1)

In EU policy discourse, the notion of a European cultural heritage is extremely abstract, referring to various intangible values, virtues, principles, and historical processes. However, the EU 
heritage initiatives aim to put the EU's abstract policy discourse into practice and concretize its notions on a European cultural heritage. For example, the candidate sites for the European Heritage Label are expected to display "their links with key European events, personalities or movements" (EC 2011, 4). A more concrete explanation of what these events, personalities, or movements might be is left to the local heritage actors applying, participating in, and implementing the initiatives.

In the EU initiatives, a European dimension of heritage is often fixed to diverse cultural and artistic styles and movements which have been canonized as European in Western art and cultural history writing. For example, in the first decision on the European Capital of Culture as an official EU action, the candidate cities applying for the title were advised "to highlight artistic movements and styles shared by Europeans which it has inspired or to which it has made a significant contribution" and "to exploit the historic heritage, urban architecture, and quality of life in the city" (EC 1999, 5) in their cultural program. The EU has also utilized the idea of a common European architectural heritage in its attempts to create common EU symbols: e.g., the Euro banknote designs illustrate different architectural motifs associated with the history of Europe. Although the "Guide for cities applying for the title of European Capital of Culture" remind that candidate cities should not only focus on "architectural heritage" or "the historical assets of the city" (EC 2009), both the first decision on the initiative and the guide itself explicate the expected elements of the designated European Capitals of Culture in the terms of cultural and artistic styles and cultural heritage (Lähdesmäki 2012).

The guide includes a list of good examples of events which have taken place in the previous European Capitals of Culture-such as in Vilnius, Graz, Lille, Luxembourg, Cork, Stavanger, and Istanbul. The represented events and "the European dimension reflected in the themes promoted" (EC 2009, 20) by the events are categorized under nine titles, with most of them either directly or indirectly highlighting the significance of cultural heritage. The categories with a direct focus on highlighting cultural heritage are: "Artistic/cultural movements and styles widely shared and known at the European level inspired by the city or to which the city has made a significant contribution," "Recent developments in artistic and cultural movements and styles," "Identifying and celebrating aspects of European history, identity, and heritage which are already present in the designated city/promotion of European public awareness of the figures and events which have marked the history and culture of the city," "Focusing on the cultural history and traditions of Europe, particular expressions of the European Union," and "Events that focus on the talents of European artists" (EC 2009, 20-2).

In EU policy discourse, the idea of a European cultural heritage is also fixed to European "personalities" or "figures." These significant historical persons, both artistic and cultural leaders with a European-wide influence and politicians considered as "founding fathers" of the EU, are used in the implementation of the EU initiatives for creating a particular European canon of Great Men (Lähdesmäki 2012). In the "Guide for cities applying for the title of European Capital of Culture," the candidate cities are advised to bring to the fore "Artistic/cultural leading figures from the city who became 'European' artists by their fame and/or their mobility and role on a European scale" and "[f]igures which were/are European but have not become as famous as their colleagues" (EC 2009, 21-2). The European Heritage Label has so far been awarded to two sites which bring to the fore a European political figure. In the report of the selection panel appointed by the Commission, the house where Robert Schuman lived is argued "to commemorate the Founding Fathers as well as to promote the history and values of the European Union" (EC 2014, 18). The Casa Alcide de Gasperi museum was awarded with the Label because "[d]e Gasperi's work is fundamental to the creation of the European Union" and as "[o]ne of the Founding Fathers of the European Union [...] he played a formative role in the reconstruction of Europe after World War II" (EC 2014, 19).

\section{Conclusions: Comparing the Notions on European Cultural Heritage}


Examination of the data revealed that the notions on a European cultural heritage greatly vary in both scholarly discussion and EU policy discourse. In both contexts European cultural heritage is given various more or less explicit meanings and is discussed through diverse contents. These contents represent a European cultural heritage as both tangible and intangible and as a communal and spatial phenomenon. Table 1 summarizes the contents of the idea of a European cultural heritage in the data and displays these contents categorized in tangible, intangible, communal, and spatial dimensions. In the table, contents commonly referred to in EU policy discourse are marked with grey.

Table 1. Contents through Which a European Cultural Heritage Has Been Defined in Scholarly Discussion and EU Policy Discourse

\begin{tabular}{|c|c|c|}
\hline & Communal & Spatial \\
\hline Tangible & $\begin{array}{l}\text { - Styles and Movements in Art and } \\
\text { Culture } \\
\text { - Important Personalities }\end{array}$ & $\begin{array}{ll}\text { - } & \text { Cities and their Historical } \\
\text { Environments } \\
\text { - } \\
\text { Architecture }\end{array}$ \\
\hline Intangible & $\begin{array}{ll}\text { - } & \text { Events } \\
\text { - } & \text { Memory of Conflicts and } \\
\text { - } & \text { Traumatic Past } \\
\text { - } & \text { EU Integration Process }\end{array}$ & $\begin{array}{ll}\text { - } & \text { Urbanity } \\
\text { - } & \text { Borders }\end{array}$ \\
\hline
\end{tabular}

The tangible dimension in the table covers phenomena that are physical, material, and "touchable," while the intangible phenomena are non-touchable ideas, conceptualizations, processes, events, memories, and knowledge. The spatial dimension in the table includes phenomena which are concretely connected to places and spatial perceptions, while the communal dimension refers to phenomena that are processual and get their meaning and are formed in social interaction. The categorization into these four dimensions is indicative and the borders between the categories are flexible and partly overlapping. The table seeks to indicate the ambiguity, multilayeredness, and varying emphasis of the idea of a European cultural heritage.

The investigation brought out that EU policy discourse emphasizes more communal than explicit spatial notions of a European cultural heritage, while in scholarly discussion the notions are often more explicitly linked to spatial contents, such as European urban areas and their environments, settings, and built heritage. However, in the implementation of the EU initiatives, the idea of a European cultural heritage is also commonly "spatialized" and concretized into a built heritage and historical and architectural monuments representing "European" artistic and architectural styles and movements. Similarly to EU policy discourse, in academia a European cultural heritage is discussed in relation to a conflicting and traumatic European past and various values perceived as penetrating the transnational political and cultural discussion climate and "mentality" in Europe. In addition, the history of the European Union was also perceived as a basis for a common cultural heritage in both contexts.

The examination indicates that EU policy discourse and scholarly discussion on European cultural heritage are closely interrelated: the concept is partly given similar contents and is often approached by emphasizing similar meanings in both contexts. In addition, the scholarly and political discussions about European cultural heritage also have a more direct link: researchers have used the EU initiatives and their narratives of building a European cultural community as data in various scholarly studies, and the European Commission and the Parliament have commissioned scholarly studies on European heritage, history, and memory (see, e.g., Prutsch 2013; Montero 2008) in order to offer expert knowledge as the basis for planning and preparing EU policies and initiatives. The ambiguity, multilayered nature, and flexibility of the idea of a European cultural heritage enable different kinds of interpretations of what characteristics, 
features, and phenomena it eventually might include. The contents and meanings of the idea are thus subjects of a constant process of negotiation.

In EU policy discourse, the ambiguity, multilayeredness, and flexibility of the idea of a European cultural heritage are easily utilized for political purposes - for promoting and justifying European identity politics and the policies and practices included in the "third wave" of the European integration process. As Cris Shore (1993, 785-6) has noted, emphasis on the EU as a humanistic enterprise based on various social virtues and common cultural roots and identity can be perceived as having functional utility. The poetic dimension of EU policy rhetoric and its emphasis on heritage is the EU's political tool in its attempts to bring the member states together and promote the political legitimacy of the EU, not only in different policy sectors but also in more emotional and intimate matters, such as strengthening a sense of belonging among Europeans, identification with Europe, and a recognition and appreciation of common European cultural roots.

\section{Acknowledgement}

This work has received funding from the Academy of Finland under Grant SA274295 (EUCHE) and the European Research Council (ERC) under the EU's Horizon 2020 research and innovation program under Grant 636177 (EUROHERIT). In addition, the work has been conducted as a part of the project BELONGING funded by Kone Foundation (Finland).

\section{REFERENCES}

Ahmad, Y. 2006. "The Scope and Definitions of Heritage: From Tangible to Intangible." International Journal of Heritage Studies 12 (3): 292-300.

Ashworth, G. J., and B. Graham. 1997. "Heritage, Identity and Europe." Tijdschrift voor Economische en Sociale Geografie 88 (4): 381-388.

Ashworth, G, B. Graham and J. Tunbridge. 2007. Pluralising Pasts: Heritage, Identity and Place in Multicultural Societies. London: Pluto Press.

Ashworth, G. J., and P. J. Larkham. 1994. "A Heritage for Europe: The Need, the Task, the Contribution." In Building a New Heritage. Tourism, Culture and Identity in the New Europe, edited by G. J. Ashworth and P. J. Larkham, 1-9. London: Routledge.

- ed. 1994. Building a New Heritage. Tourism, Culture and Identity in the New Europe. London: Routledge.

Banús, E. 2015. Keynote speech in the 13th International Conference European Culture, held 2931 October 2015 at the Babeș-Bolyai University, Cluj-Napoca, Romania.

Benevolo, L. 1993. The European City. The Making of Europe. Oxford: Blackwell.

CofE. 2005. Council of Europe Framework Convention on the Value of Cultural Heritage for Society. Faro, 27 October 2005. http://www.coe.int/en/web/conventions/full-list//conventions/rms/0900001680083746.

Delanty, G. 2002. "Models of European Identity: Reconciling Universalism and Particularism." Perspectives on European Politics and Society 3 (3): 345-359.

- 2005. "The Idea of a Cosmopolitan Europe: On the Cultural Significance of Europeanization.” International Review of Sociology 15:3, 405-421.

- 2009. "The European Heritage: History, Memory, and Time." In The Sage Handbook of European Studies, edited by C. Rumford, 36-51. London: Sage.

Delanty, G., and P. R. Jones. 2002. "European Identity and Architecture." European Journal of Social Theory 5 (4): 453-466. 
Delanty, G., and C. Rumford. 2005. Rethinking Europe. Social Theory and the Implications of Europeanization. London: Routledge.

Diner, D. 2003. "Restitution and Memory: The Holocaust in European political cultures." New German Critique 90: 36-45.

Dolff-Bonekämper, G. 2004. "Introduction.” In Dividing Lines, Connecting Lines. Europe's Cross-Border Heritage, edited by G. Dolff-Bonekämper, 11-16. Strasbourg: Council of Europe Publishing.

EC. 1999. Decision 1419/1999/EC of the European Parliament and of the Council of 25 May 1999 establishing a Community action for the European Capital of Culture event for the years 2005 to 2019. Official Journal of the European Communities L 166: 1-5.

2009. Guide for Cities Applying for the Title of European Capital of Culture. Brussels: European Commission.

2010. The Memory of the Crimes Committed by Totalitarian Regimes in Europe. Report from the Commission to the European Parliament and to the Council (COM(2010) 783 final). Brussels: European Commission.

2011. Decision No 1194/2011/EU of the European Parliament and of the Council of 16 November 2011 Establishing a European Union Action for the European Heritage Label. Official Journal of the European Union L 303: 1-9.

2012. Consolidated Version of the Treaty on European Union. Official Journal of the European Union C 326/13: 329-90.

2014a. European Heritage Label. Panel Report 19 December 2014. Brussels: European Commission.

2014b. Council Conclusions Of 21 May 2014 on Cultural Heritage as a Strategic Resource for a Sustainable Europe. Official Journal of the European Union C 183: 3638.

EP. 2012. Parliament's Position on the 2011 Draft Budget as Modified by the Council - all sections (P7_TA(2010)0372). Official Journal of the European Union CE 70: 149-161.

Foote, K. 1997. Shädowed Ground: America's Landscapes of Violence and Tragedy. Austin: University of Texas Press.

Graham, B. 2002. "Heritage as Knowledge: Capital or Culture?" Urban Studies 39:1003-1017.

Graham, B, G. Ashworth, and J. Tunbridge. 2000. A Geography of Heritage: Power, Culture and Economy. London: Hodder Arnold Publication.

Howard, P., and G. J. Ashworth. 1999. European Heritage. Planning and Management. Exeter: Intellect Books.

Jarausch, K. H. 2010. "Nightmares or Daydreams? A Postscript on the Europeanisation of Memories." In A European Memory? Contested Histories and Politics of Remembrance, edited by M. Pakier and B. Stråth, 309-320. New York: Berghahn Books.

Jenkins, R. 2008. "The Ambiguity of Europe: 'Identity Crisis' or 'Situation Normal'?" European Societies 10 (2): 153-176.

Jones S., and J. Subotic. 2011. "Fantasies of Power: Performing Europeanization on the European Periphery." European Journal of Cultural Studies 14 (5): 542-557.

Karlsson, K-G. 2010. "The Uses of History and the Third Wave of Europeanisation." In A European Memory? Contested Histories and Politics of Remembrance, edited by $\mathrm{M}$. Pakier and B. Stråth, 38-55. New York: Berghahn Books.

Kohli, M. 2000. “The Battlegrounds of European Identity.” European Societies 2 (2): 113-137.

Kuutma, K. 2012. "Between Arbitration and Engineering: Concepts and Contingencies in the Shaping of Heritage Regimes." In Heritage Regimes and the State, edited by R. F. Bendix, A. Eggert and A. Peselmann, 21-36. Göttingen: Universitätsverlag Göttingen.

Kuipers, M., and J. Schofield. 2004. "Lines of Tension." In Dividing Lines, Connecting Lines. Europe's Cross-Border Heritage, edited by G. Dolff-Bonekämper, 29-47. Strasbourg: Council of Europe Publishing. 
Lähdesmäki, T. 2012. "Rhetoric of Unity and Cultural Diversity in the Making of European Cultural Identity." International Journal of Cultural Policy 18 (1): 59-75.

- 2015. "The Problematic of Conceptualizing Transcultural Heritage in Europe". Paper presented in the 8th Global Conference on Interculturalism, Meaning \& Identity held in 14-16 March 2015 in Lisbon, Portugal. http:/www.inter-disciplinary.net/at-theinterface/wp-content/uploads/2015/02/L\%C3\%A4hdesm\%C3\%A4ki-T-IC8-wpaper.pdf. 2016. "Scholarly Discussion as Engineering the Meanings of a European Cultural Heritage." European Journal of Cultural Studies: 1-18. DOI: 10.1177/1367549416631996.http://ecs.sagepub.com/cgi/reprint/1367549416631996v1.p df?ijkey=4B91V2K0sm0jlpb\&keytype=finite.

Larkham, P. J. 1994. “A New Heritage for a New Europe.” In Building a New Heritage. Tourism, Culture, and Identity in the New Europe, edited by G. J. Ashworth and P. J. Larkham, 260-273. London: Routledge.

Lowenthal, D. 1998. The Heritage Crusade and the Spoils of History. Cambridge: Cambridge University Press.

2005. "Natural and Cultural Heritage.” International Journal of Heritage Studies 11 (1): 81-92.

Macdonald, S. 2009. Difficult Heritage. Negotiating the Nazi Past in Nuremberg and Beyond. New York: Routledge.

Miles, M. B., and A. M. Huberman. 1994. Qualitative Data Analysis: An Expanded Sourcebook. Thousand Oaks: Sage.

Montero, C. C. 2008. Study on how the Memory of Crimes Committed by Totalitarian Regimes in Europe is Dealt with in the Member States. JLS/2008/C4/006. Brussels: European Commission.

Näss, H. E. 2009. A New Agenda? The European Union and Cultural Policy. London: Alliance Publishing Trust.

2010. The Ambiguities of Intercultural Dialogue: Critical Perspectives on the European Union's New Agenda for Culture. Journal of Intercultural Communication 23. http://www.immi.se/intercultural/.

Niznik, J. 2013. "Preface. The Social Instruments of European Memory.” In Twentieth Century Wars in European Memory, edited by J. Niznik, 9-17. Frankfurt: Peter Lang.

O'Callaghan, C. 2011. Urban Anxieties and Creative Tensions in the European Capital of Culture 2005: 'It Couldn't Just Be about Cork, Like'. International Journal of Cultural Policy 18 (2): 185-204.

Pakier, M. 2010. "A Europeanisation of the Holocaust Memory?" In A European Memory? Contested Histories and Politics of Remembrance, edited by M. Pakier and B. Stråth B, 191-203. New York: Berghahn Books.

and B. Stråth. 2010. "Introduction. A European Memory?" In A European Memory? Contested Histories and Politics of Remembrance, edited by M. Pakier and B. Stråth B, 1-20. New York: Berghahn Books.

Patel, K. K. 2013. "Introduction." In: The Cultural Politics of Europe. European Capitals of Culture and European Union Since the 1980s, edited by K. K. Patel, 1-15. London: Routledge.

Prutsch, M. J. 2013. European Historical Memory: Policies, Challenges and Perspectives. Directorate-General for Internal Policies. Policy Department B: Structural and Cohesion Policies. Culture and Education. Brussels: European Parliament.

Risse, T. 2003. "European Identity and the Heritage of National Culture." In: Rethinking Heritage. Cultures and Politics in Europe, edited by R. S. Peckham, 74-89. London: I.B.Tauris.

2010. A Community of Europeans? Transnational Identities and Public Spheres. New York: Cornell University Press. 
Rosamond, B. 2000. Theories of European Integration. Basingstoke: Palgrave.

Said, E. W. 1985. Orientalism. London: Penguin Books.

Sassatelli, M. 2006. "The Logic of Europeanizing Cultural Policy." In Transcultural Europe. Cultural Policy in a Changing Europe, edited by U. H. Meinhof and A. Triandafyllidou, 24-42. Basingstoke: Palgrave MacMillian.

- 2008. "European Cultural Space in the European Cities of Culture." European Societies 10 (2): 225-245.

-. 2009. Becoming Europeans. Cultural Identity and Cultural Policies. New York: Palgrave Macmillan.

Shore, C. 1993. "Inventing the 'People's Europe': Critical Approaches to European Community 'Cultural Policy"”. Man 28 (4): 779-800.

Smith, L. 2006. Uses of Heritage. London: Routledge.

Tesch, R. 1990. Qualitative Research: Analysis Types and Software Tools. Bristol: Falmer.

Tunbridge, J. E. 1994. "Whose Heritage? Global Problem, European Nightmare.” In Building a New Heritage. Tourism, Culture and Identity in the New Europe, edited by G. J. Ashworth and P. J. Larkham, 123-134. London: Routledge.

UNESCO. 2003. Convention for the Safeguarding of the Intangible Cultural Heritage. Paris, 17 October 2003. http://unesdoc.unesco.org/images//0013/001325/132540e.pdf.

Vecco, M. 2010. "A Definition of Cultural Heritage: From the Tangible to the Intangible." Journal of Cultural Heritage 11 (3): 321-324.

Vos, C. 2011. "Negotiating Serbia's Europeanness. On the Formation and Appropriation of European Heritage Policy in Serbia." History and Anthropology 22 (2): 221-242.

Yeoh, B., and L. Kong. 1997. "The Notion of Place in the Construction of History, Nostalgia and Heritage in Singapore." Singapore Journal of Tropical Geography 17 (1): 52-65.

\section{ABOUT THE AUTHOR}

Tuuli Lähdesmäki, PhD: Academy of Finland Research Fellow, Department of Art and Culture Studies, University of Jyväskylä, Jyväskylä, Finland. 